University of Nebraska - Lincoln

DigitalCommons@University of Nebraska - Lincoln

Faculty Publications - Textiles, Merchandising and Fashion Design

Textiles, Merchandising and Fashion Design,

Department of

$1-2005$

\title{
Biofibers from agricultural byproducts for industrial applications
}

Narendra Reddy

University of Nebraska - Lincoln, nreddy3@unl.edu

Yiqi Yang

University of Nebraska-Lincoln, yyang2@unl.edu

Follow this and additional works at: https://digitalcommons.unl.edu/textiles_facpub

Part of the Art and Design Commons

Reddy, Narendra and Yang, Yiqi, "Biofibers from agricultural byproducts for industrial applications" (2005). Faculty Publications - Textiles, Merchandising and Fashion Design. 28.

https://digitalcommons.unl.edu/textiles_facpub/28

This Article is brought to you for free and open access by the Textiles, Merchandising and Fashion Design, Department of at DigitalCommons@University of Nebraska - Lincoln. It has been accepted for inclusion in Faculty Publications - Textiles, Merchandising and Fashion Design by an authorized administrator of DigitalCommons@University of Nebraska - Lincoln. 


\title{
Biofibers from agricultural byproducts for industrial applications
}

\author{
Narendra Reddy and Yiqi Yang \\ Department of Textiles, Clothing and Design and Department of Biological Systems Engineering, \\ University of Nebraska-Lincoln, 234 HE Bldg, Lincoln, Nebraska 68583-0802, USA \\ Corresponding author —Yiqi Yang, yyang2@unl.edu
}

\begin{abstract}
Lignocellulosic agricultural byproducts are a copious and cheap source for cellulose fibers. Agro-based biofibers have the composition, properties and structure that make them suitable for uses such as composite, textile, pulp and paper manufacture. In addition, biofibers can also be used to produce fuel, chemicals, enzymes and food. Byproducts produced from the cultivation of corn, wheat, rice, sorghum, barley, sugarcane, pineapple, banana and coconut are the major sources of agro-based biofibers. This review analyses the production processes, structure, properties and suitability of these biofibers for various industrial applications.
\end{abstract}

Depleting natural resources, regulations on using synthetic materials, growing environmental awareness and economic considerations are the major driving forces to utilize annually renewable resources such as biomass for various industrial applications [see Kozlowski, R. (1987) Green fibers and their potential in diversified application; http://www.fao.org/DOCREP/004/Y1873E/y1873eob.htm] [1, 2]. Biomass such as agricultural crops and residues, forest resources and residues, animal and municipal wastes is the largest source for cellulose in the world. Approximately $2 \times 10^{11}$ tons of lignocellulosics are produced every year, compared with $1.5 \times 10^{8}$ tons of synthetic polymers [2]. Organic agricultural wastes (agricultural byproducts) are annually renewable, available in abundance and of limited value at present. These lignocellulosic byproducts could be a principal source for fibers, chemicals and other industrial products. Primary lignocellulosic agricultural byproducts that are available in considerable quantity and at low cost are corn stover, wheat, rice, barley straw, sorghum stalks, coconut husks (coir), sugarcane bagasse, and pineapple and banana leaves. Using these crop residues for industrial applications could be an additional source of revenue for farmers, without adversely affecting soil fertility (http://www.fao. org/DOCREP/004/Y1873E/y1873eob.htm).

Not all of these agricultural byproducts are commonly available across the world. Many are native to a particular region, depending on the climatic conditions required to grow the food crops. The value of the byproduct depends on the availability and potential use of the byproduct. In developing countries, the use of agricultural byproducts for fibers, fuels and chemicals would be more valuable than in other countries but most of the agricultural byproducts are used as a source of fuel or animal feed and therefore do not add much value to the crops [3]. The Technology Road Map for Plant/Crop Based Renewable Resources 2020, sponsored by the Department of Energy (DOE) in the USA, has a target to achieve $10 \%$ of basic chemical building blocks from plant derived renewable sources and to increase the share to $50 \%$ by 2050 [2].

Lignocellulosics are used for various applications, depending on their composition and physical properties. Wheat and rice straw, and even corn stalks to a limited extent, have traditionally been used for pulp and paper making [4-6]. Coir, pineapple and banana leaves have been used as natural cellulose fiber source for textiles, composites and also for paper [4-8]. Recently, natural cellulose fibers suitable for textile and other industrial applications have been produced from corn husks and corn stalks $[9,10]$. Rice and wheat straw have also been used to produce regenerated cellulose fibers as an alternative to wood for cellulose-based materials [6, 11]. Increase in fuel costs and scarcity of petroleum sources led to the use of lignocellulosics to produce ethanol and other sugars by fermentation. Biomasses can also be converted into carbon, hydrogen and oxygen to produce various chemicals, enzymes and proteins.

\section{Fiber extraction}

Natural cellulose fibers are extracted from lignocellulosic byproducts using bacteria and fungi, mechanical and chemical methods. Retting, the traditional process to extract fibers, uses bacteria and fungi in the environment to remove lignin, pectin and other substances. Bacteria such as Bacillus and Clostridium, used in water retting, and fungi such as Rhizomucor pusillus and Fusarium lateritium, used in dew retting, are found to be most effective in their ability to attack the noncellulosic substances and separate the fibers from the core [12, 13]. Although atmospheric retting provides better quality fibers, it requires relatively longer duration and it is difficult to control the fiber quality.

The relatively more common chemical retting methods use alkalis, mild acids and enzymes for fiber extraction. Sodium hydroxide is the most commonly used chemical for fi- 
ber extraction. Acids such as sulfuric acid and oxalic acid in combination with a detergent have also been used for fiber extraction [13, 14]. Chemical concentration, temperature and duration of treatment are the main factors determining the quality of chemically extracted fibers [14]. For enzymatic fiber extraction, a combination of enzymes such as pectinases, hemicellulases and cellulases are generally used with a preor postchemical treatment. Recently, multienzyme complexes that can express 10-15 enzyme activities and provide better fiber quality have been developed [see Hans Sejr, O. (2004) Enzymes at work; http://www.novozymes.com].

Mechanical separation of fibers is carried out using decorticating machines, steam explosion (STEX), ammonia fiber extraction, Tilby process and similar methods [11, 15, 16]. The Tilby cane separation process separates sugarcane into the outer skin, rind and sugar-containing pith. The outer skin contains wax that can be extracted for use in pharmaceutical products. The separated rind can be used for the manufacture of paper, panels and boards. After extracting the sugar, the pith can be used for the manufacture of fiber boards, absorbents and fillers. The Tilby process would also be suitable for processing corn, sorghum and other lignocellulosic plant stalks [17]. This process offers the advantage of separating the plant components without disintegrating their constituents, which can be further treated to extract fibers and other bioproducts. Cellulose fibers suitable for textile, paper, composite and other applications have been extracted from wheat straw and rind of sugarcane by the Tilby process and also by steam explosion [11, 17].

Rayon, the first regenerated cellulose fiber, became popular owing to the shortage of natural fibers, large availability of renewable forest resources and its relatively low price. The most common rayon production process uses sodium hydroxide and carbon disulphide to form a xanthate solution which is ripened and extruded into a sulfuric acid coagulation bath to form regenerated cellulose [18]. However, the development of cheaper synthetic fibers, environmental concerns owing to the use of carbon disulphide, and depleting forest resources led to the fall of rayon. In recent years, an environmentally friendly lyocell process based on the $N$-methylmorpholine- $N$-oxide monohydrate (NMMO) solvent system is being widely used for the production of regenerated cellulose $[6,11]$. The possibility of using agricultural byproducts for producing rayon, the development of the environmentally friendly lyocell process and concerns on the price and availability of petroleumbased fibers could renew interest in rayon and make it a preferred fiber in the near future.

\section{Chemical composition of fibers}

The chemical composition of lignocellulosics is inherent according to the particular needs of the plants. Cellulose, hemicellulose and lignin are the three main constituents of any lignocellulosic source, and the proportion of these components in a fiber depends on the age, source of the fiber and the extraction conditions used to obtain the fibers [19]. Natural cellulose fibers are composed of individual cells that are commonly referred to as 'Ultimates'. Cotton and kapok have ultimates that are long enough to be used as unicellular fibers. All other natural cellulose fibers are multicellular, with a bundle of individ- ual cells bound by natural polymers such as lignin and pectin $[19,20]$. In this review, 'fibers' refer to a bundle of individual cells with adequate strength, length and fineness required for various fibrous industrial applications. Individual cells in agro-based fibers are too small to be used for textile and other high-quality fibrous applications but can be used for paper and similar applications [20].

Cellulose is the main structural component that provides strength and stability to the plant cell walls and the fiber [21]. The amount of cellulose in a fiber influences the properties, economics of fiber production and the utility of the fiber for various applications. For example, fibers having higher cellulose content would be preferable for textile, paper and other fibrous applications, whereas byproducts with higher hemicellulose content would be preferable for producing ethanol and other fermentation products because hemicellulose is relatively easily hydrolysable into fermentable sugars. Therefore, the value of the byproduct and its potential application is to a large extent determined by the cellulose content. However, it should be noted that the value of the byproduct depends on the quality of the fibers obtained and their end use, and not on the cellulose content per se. As seen from Table 1, pineapple and banana fibers have a higher cellulose content, which is probably related to the relatively higher weight of the fruit they support and the fact that they are less perishable. Other fiber sources such as corn stover, bagasse, wheat, rice and barley straw, and sorghum stalks all contain nearly the same amount of cellulose. Fibers in these crops support relatively smaller weights in comparison with bananas and pineapples.

Hemicellulose in plants is slightly crosslinked and is composed of multiple polysaccharide polymers with a degree of polymerization and orientation less than that of cellulose [22]. Hemicellulose usually acts as filler between cellulose and lignin and consists of sugars including glucose, xylose, galactose, arabinose and mannose. Mechanically, hemicellulose contributes little to the stiffness and strength of fibers or individual cells [23]. Hemicellulose is more easily hydrolyzed into sugars than cellulose and therefore fibers containing a higher proportion of hemicellulose would be preferable for producing sugars, and eventually for fuels such as ethanol. Wheat and rice straw, corn stover and bagasse are, to a certain extent, favorable for producing carbohydrates because of their higher hemicellulose content and relatively larger availability. In comparison, coir and banana fibers have low hemicellulose content, and using these fibers to produce carbohydrates might not be economical owing to the low conversion rates possible.

Lignin is a highly crosslinked molecular complex with amorphous structure and acts as glue between individual cells and between the fibrils forming the cell wall [2]. Lignin is first formed between neighboring cells in a "middle lamella," bonding them tightly into a tissue, and then spreads into the cell wall penetrating the hemicelluloses and bonding the cellulose fibrils [4]. Lignin provides plant tissue and individual fibers with compressive strength and stiffens the cell wall of the fibers to protect the carbohydrates from chemical and physical damage [24]. The lignin content of the fibers influences the structure, properties, morphology, flexibility and rate of hydrolysis [25]. Fibers with higher lignin content appear finer 
Table I. Availability and composition of biofibers

\begin{tabular}{lcccccc}
\hline Fiber source & $\begin{array}{c}\text { Availability } \\
10^{3} \text { tons }\end{array}$ & $\begin{array}{c}\text { Cellulose } \\
\%\end{array}$ & $\begin{array}{c}\text { Hemicellulose } \\
\%\end{array}$ & $\begin{array}{c}\text { Lignin } \\
\%\end{array}$ & $\begin{array}{c}\text { Ash } \\
\%\end{array}$ & References \\
\hline Corn stover & 727 & $38-40$ & 28 & $7-21$ & $3.6-7.0$ & {$[9,10]$} \\
Pineapple leaf fiber & - & $70-82$ & 18 & $5-12$ & $0.7-0.9$ & {$[4,7,14,25]$} \\
Coir & 100 & $36-43$ & $0.15-0.25$ & $41-45$ & $2.7-10.2$ & {$[4,7,19,39]$} \\
Bagasse & 100 & $32-48$ & $19-24$ & $23-32$ & $1.5-5$ & {$[22]$} \\
Banana & - & $60-65$ & $6-8$ & $5-10$ & 4.7 & {$[4,7,8]$} \\
Wheat straw & 568 & $33-38$ & $26-32$ & $17-19$ & $6-8$ & {$[22,40]$} \\
Rice straw & 579 & $28-36$ & $23-28$ & $12-14$ & $14-20$ & {$[22,43]$} \\
Sorghum stalks & 252 & 27 & 25 & 11 & -14 & {$[22,40]$} \\
Barley straw & 195 & $31-45$ & $27-38$ & $14-19$ & $2-7$ & {$[22]$} \\
\hline
\end{tabular}

and will be more flexible [25]. Generally, fibers with a lower amount of cellulose have a higher lignin content, as seen from Table 1. Lignin can range from water soluble (lignosulfonates) to insoluble (kraft lignin), even in general organic solvents such as acetone.

Ash present in lignocellulosics, especially straw, contains silica that has many undesirable effects [5]. Silica blunts cutting machinery, reduces the digestibility of straw, interferes with the pulping process by forming scales on the surface of the reactors and makes combustion more difficult [5].

\section{Fiber structure}

The dimension and arrangement of unit cells in a fiber determine the structure and also influence the properties of the fibers. The dimensions of individual cells or 'ultimates' in natural fibers are dependent on the species, maturity and location of the fibers in the plant and also on the fiber extraction conditions $[12,13]$. Individual cells in pineapple and banana fibers are relatively longer and therefore these sources can produce long fibers. The widths of individual cells in rice straw, wheat straw and corn husk are smaller and can therefore form relatively finer fibers. As shown in Table 2, coir has thick individual cells and therefore cannot form fine fibers. When used for applications such as textiles and paper, the length to diameter ratio $(1 / \mathrm{d})$ of individual cells in a fiber affects the flexibility and resistance to rupture of the fibers and products made from them $[20,26]$. Wheat and rice straw have high $1 / \mathrm{d}$ ratios and are therefore more commonly used in the manufacturing of paper.
Biofibers do not show the general relationship between crystallinity and strength observed in pure cellulose fibers such as cotton and rayon, that is, the higher the crystallinity, the higher the strength. The presence of substantial amounts of noncellulosics, mainly lignin, which contributes to the strength of fibers and the variations in the dimensions of unit cells, is the major reason for the absence of a good relationship between crystallinity and strength. However, biofibers with longer unit cells have higher strength, as seen from Table 2. Therefore, the amount of noncellulosics and dimensions of the unit cells in the fiber are to be considered when designing products using biofibers.

In their natural state, and before chemical extraction, fiber surfaces have waxes and other encrusting substances such as hemicellulose, lignin and pectin that form a thick outer layer to protect the cellulose inside. The presence of encrusting substances causes the fibers to have an irregular appearance, as shown in Figure 1. During fiber extraction, most of the surface waxes and other noncellulosic substances are removed, as shown in Figure 2. When agro-based fibers are used as reinforcing fibers for composites, the removal of surface waxes and encrusting substances makes the fiber surface rough and improves the adhesion of fibers and polymer matrix [27, 28]. The presence of impurities on the surface of the fibers affects the appearance and processability of the fibers [10]. Chemical, biological and physical treatments are used to improve the morphological features, processability and utility of the fibers [10, 28].

Transversally, unit cells in all of the biofibers have a central hollow cavity called the lumen. The shape (round, polygonal or elliptical) and size of the lumen depends on the source of

Table 2. Structure and properties of biofibers

\begin{tabular}{|c|c|c|c|c|c|c|c|}
\hline \multirow[t]{3}{*}{ Fiber } & \multicolumn{3}{|c|}{ Fiber structure } & \multicolumn{3}{|c|}{ Fiber properties } & \multirow[b]{3}{*}{ References } \\
\hline & \multicolumn{2}{|c|}{ Cell dimensions } & \multirow[t]{2}{*}{ Crystallinity \% } & \multirow{2}{*}{$\begin{array}{l}\text { Tenacity } \\
\text { g/den }{ }^{\mathrm{a}}\end{array}$} & \multirow[t]{2}{*}{ Elongation \% } & \multirow{2}{*}{$\begin{array}{l}\text { Moisture } \\
\text { content \% }\end{array}$} & \\
\hline & Length (mm) & Width $(\mu \mathrm{m})$ & & & & & \\
\hline PALFb & $3-9$ & $20-80$ & $44-60$ & $0.7-3.8$ & $0.8-1.6$ & $10-13$ & {$[7,14,27,41,42]$} \\
\hline Coir & $0.3-1.0$ & $100-450$ & $27-33$ & 2.0 & $17-47$ & $10-12$ & {$[7,19,30,39]$} \\
\hline Bagasse & $0.8-2.8$ & $10-34$ & - & $0.9-1.25$ & $5.5-11.8$ & 8.8 & {$[22,43]^{c}$} \\
\hline Rice straw & $0.4-3.4$ & $4-16$ & 40 & - & - & 6.5 & {$[6,22]$} \\
\hline Sorghum stalks & $0.8-1.2$ & $30-80$ & - & - & - & $8-12$ & {$[22]^{c}$} \\
\hline Barley straw & $0.7-3.1$ & $7-24$ & - & - & - & $8-12$ & {$[24]^{c}$} \\
\hline
\end{tabular}

a. Denier is defined as the weight in grams per $9000 \mathrm{~m}$ of the fiber.

b. PALF, pineapple leaf fiber.

c. See also Hurter, R.W. et al. (200I) Nonwood plant fiber characteristics.TAPPI I 997 Nonwood Fibers Short Course Notes; http://www. HurterConsult.com . 


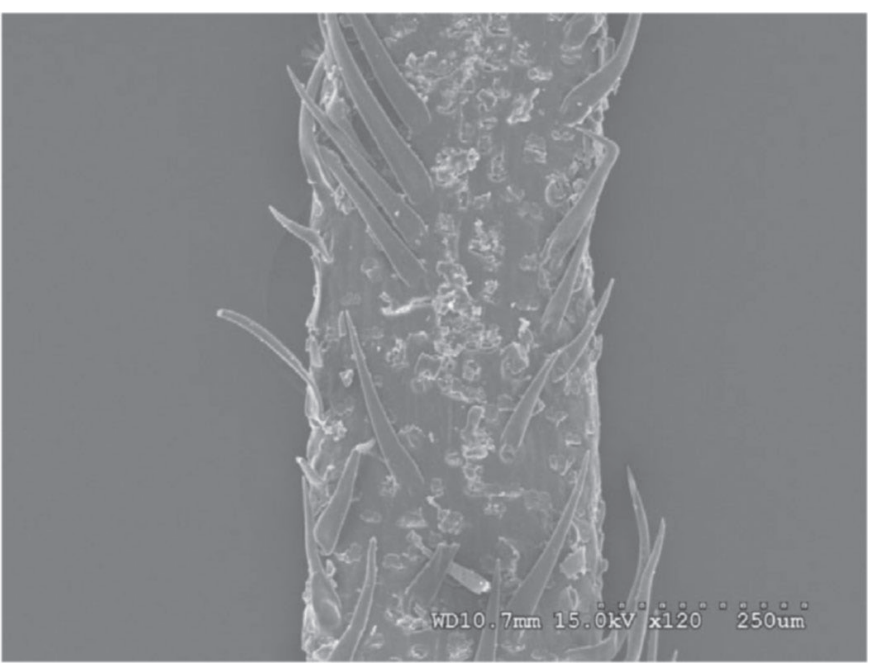

Figure I. Scanning electron micrograph of an untreated strand mechanically extracted from corn husk.

the fiber and thickness of the cell wall [25]. The presence of the hollow lumen decreases the bulk density of the fiber and acts as an acoustic and thermal insulator. These properties make biofibers preferable for lightweight composites used as noise and thermal insulators in automobiles [29].

\section{Fiber properties}

The amount of cellulose and noncellulosic constituents in a fiber determine the structure and properties and influence its crystallinity and moisture regain [30]. Properties such as density, electrical resistivity, tensile strength, modulus, moisture regain and crystallinity are related to the composition and internal structure of the fibers. Although the strength of fibers cannot be exactly correlated to the cellulose content and microfibrillar angle, generally, fibers with higher cellulose content, higher degree of polymerization of cellulose and lower microfibrillar angle give better mechanical properties [25]. Fibers with higher lignin content, lower $1 / \mathrm{d}$ ratio and higher microfibrillar angle show lower strength and modulus but have higher extensibility. The higher amount of cellulose and the lower spiral angle in banana fibers give the fibers higher modulus and tensile strength but lower breaking elongation compared with coir fibers [8].

The mechanical properties of natural fibers are influenced by the composition, structure and number of defects in a fiber. Under stress, tensile failure occurs by intercellular and/ or intracellular modes. In fibers having higher cellulose content such as those in bananas and pineapples, cracks propagate through weak bonding between cells, causing intercellular fracture without the removal of microfibrils [25]. By contrast, cracks propagate through the cells in fibers with lower cellulose content such as coir, resulting in intracellular fracture with microfibrillar pullout $[8,25]$. Elongation of fibers depends on the degree of crystallinity, orientation and the angle of the microfibrils to the fiber axis. The high extensibility of coir fibers is primarily a result of the perfect helical spirals formed by the microfibrils around the fiber axis [30].

Cellulosic fibers change their dimensions and properties with varying moisture content [2]. The extent of changes in

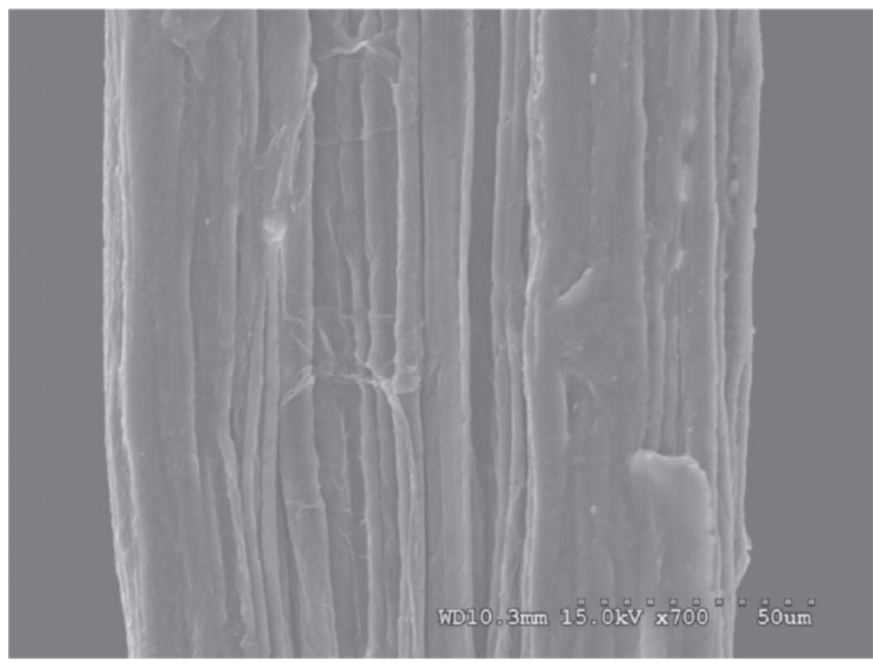

Figure 2. Scanning electron micrograph of a partially purified fiber bundle from corn husks.

a fiber is determined by the amount of hemicellulose, lignin, crystallinity and surface characteristics of the fibers [2]. Moisture content in fibers influences the degree of crystallinity, crystallite orientation, tensile strength, swelling behavior and porosity of vegetable fibers [25]. An increase in moisture content decreases the electrical resistivity and affects the dimensional stability of composites made from cellulosic fibers [2, 25]. The ability of a fiber to absorb or desorb moisture should be considered when evaluating the suitability of fibers for various applications, especially for textiles, paper and composites.

\section{Applications}

Fibers from lignocellulosic sources are used in various applications such as building materials, particle boards, insulation boards, human food and animal feed, cosmetics, medicine and for other biopolymers and fine chemicals (http:// www.fao.org/DOCREP/004/Y1873E/y1873eob.htm) [6, 3133]. Chemicals such as ammonia, carbon, methanol, ethanol, pyroligneous acid, charcoal, acetic acid, acetone and hydrocarbon oils are also produced from lignocellulosics by hydrolysis and fermentation [4]. Cellulose and hemicellulose can be used for producing single-cell proteins, cellulolytic enzymes and mushrooms [4]. Fibers obtained from straw can be used to produce all kinds of paper and paper boards, without using any wood pulp. Table 3 shows some of the common chemicals and products from the cellulose, hemicellulose and lignin components in agricultural byproducts.

Hemicellulose in lignocellulosics can be used to produce resins and plastics, pharmaceuticals, furfurylalcohol, monochloroacetic acid, herbicides, tetrahydrofufurylic alcohol and maleic anhydride $[34,35]$. The process of chemical pulping can also produce cellophane, carboximethylcellulose, cellulose acetate, cellulose nitrate, cellulose amide, chromatographic bases and other chemicals [see Almazan, O. et al. (1998) The sugarcane, its by-products and co-products. Sugarcane International; http:// www.uom.ac.mu/Faculties/foa/AIS/AMAS98/.htm]. Xylans, mannans and galactans extracted from hemicellulose are used as thickeners, stabilizers and emulsifiers, and as gels in the food, pharmaceutical and paper industries. 
Table 3. Chemicals and products from the major constituents of biofibers

\begin{tabular}{llll}
\hline Products and chemicals & Biomass source & Biomass component & References \\
\hline Fibers for textiles and composites & Corn stover, PALF , coir, banana leaves & Cellulose & {$[4,7,8,10,14]$} \\
Fibers for pulp and paper & Rice and wheat straw, corn stover & Cellulose & {$[5,6, I I, 22]$} \\
Fiber-reinforced starch foams & Corn stalks & Cellulose & {$[9]$} \\
Single-cell proteins & All biomasses & Cellulose & {$[4,26,31,46]$} \\
Adhesives and binders & All lignin-containing biomasses & Lignin & {$[21,26,35,46,47]^{\mathrm{b}}$} \\
Lactic acid & Corn stover & Cellulose & {$[2,21]$} \\
Strawboard & Wheat and rice straw & Cellulose & {$[5,22,24,32,37,38]^{\mathrm{c}}$} \\
Solvents & Bagasse & Cellulose & {$[32,46]^{\mathrm{b}}$} \\
Furfural & All biomasses & Cellulose & {$[21,35,46,47]^{\mathrm{b}}$} \\
Dyes, pigments and ink & All biomasses & Hemicellulose & {$[21,26,35,46,47]^{\mathrm{b}}$} \\
Electricity & Straw & Lignin & {$[36,47]$} \\
Surfactants and coagulants & Wheat straw & Hemicellulose & {$[26,36,47]^{\mathrm{b}}$} \\
Urea & All biomasses & Lignin & {$[4,26,31,33]$} \\
Pharmaceuticals & Bagasse & Lignin & {$[6,31,32,33]^{\mathrm{c}}$} \\
Ethanol and other alcohols & Corn stover, wheat, rice and bagasse & Hemicellulose & {$[1,21,23,46,47]$} \\
\hline
\end{tabular}

a. PALF, pineapple leaf fiber.

b. See also Almazan, O. et al. (1998) The sugarcane, its by-products and co-products. Sugarcane International; http://www.uom.ac.mu/Faculties/foa/AIS/ AMAS98/htm

c. See also Kozlowski, R. (1987) Green fibres and their potential in diversified application; http://www.fao.org/DOCREP/004/YI873E/y/873eob.htm

Lignin is commonly used as a fuel for burning because it has high energy content and fuel value but these applications provide limited additional value [36]. However, various chemicals such as phenols, acetic acid, charcoal and ethylene can be produced from lignin, which could make lignin as valuable as the cellulose and hemicellulose components in biomasses [36, 37].

Adhesives produced from lignin are used in composites, packaging, laminates, stiffening agents and plastic molding (http://www.fao.org/DOCREP/004/Y1873E/y1873eob.htm). Silica recovered from the pulping of rice and wheat straw can be made into bricks, ceramic items and glassware.

Biofibers are used for composites because of their low cost, low density, high toughness, reduced dermal and respiratory irritation, ease of separation, enhanced energy recovery and biodegradability [38]. Natural fibers provide stiffness and strength to the composites, are easily recyclable and, unlike brittle fibers such as glass, biofibers will not be fractured when processing over sharp curvatures. Biofibers also compete well in terms of strength per weight of the material when compared with conventional fibers such as glass and mica used for composites [28]. Biocomposites are used in motor vehicles, furniture, machine construction and insulating materials (http://www.fao.org/DOCREP/004/Y1873E/y1873eob.htm) [32]. Prefabricated panelized constructions made from bagasse and plastered with cement are used for structures that are resistant to earthquakes [32].

\section{Limitations}

The major limitations of using agricultural byproducts are the lack of an established collection, storage, and handling systems that would prevent the degradation of the lignocelluosics when stored for a considerable period. The enormous amount of research being carried out in producing ethanol from lignocellulosic biomasses is addressing these issues. It is reasonable to expect that agricultural byproducts will be a major source of industrial products and chemicals in the near future. However, there are a few limitations associated with agro-based fi- bers that should be considered when designing products using biofibers.

The primary limitation of the use of agro-fibers for composites is the lower processing temperature permissible, owing to the possibility of lignocellulosic degradation. This limits the processing temperatures and the type of thermoplastics that can be used with agro-fibers to produce composites [37]. The second limitation is the relatively higher moisture absorption of natural fibers, making it difficult for the hydrophobic fibers and hydrophilic polymers to bond together [28, 29, 31]. These limitations and the variability of natural fibers are of concern when selecting materials for composites [28]. In pulp and paper manufacture, silica present in fibers (3\% to $14 \%$ in rice and wheat straw) accumulates and causes scaling in evaporator tubes, reducing the efficiency of the pulping process [5].

\section{Conclusions}

The potential availability and economics of using agrobased fibers far outweigh their limitations. An increasing population and constraints on using natural resources to grow fiber crops make agro-based fibers the most promising alternative to natural fibers. Current ethanol processors and biorefineries are using all the major components of biomass (cellulose, hemicellulose and lignin) to produce fuels and chemicals. Increasing the value of coproducts by using the major components of biomass is necessary to make ethanol competitive with fossil fuels and for biorefineries to be sustainable in the long term. Such attempts will increase the availability of coproducts suitable for producing various chemicals and products and will reduce our dependence on nonrenewable energy sources. The future seems to be bright for biofibers and biobased products.

Acknowledgments - We are indebted for the financial support from the University of Nebraska-Lincoln Agricultural Research Division (Journal Series No. 14699) and the support through the Hatch Act. 


\section{References}

1 Van Wyk, J. P. H. (2001) Biotechnology and the utilization of biowaste as a resource for bioproduct development. Trends BioTechnol. 19, 5, 172-177.

2 A. K. Mohanty et al., Biofibres, biodegradable polymers and biocomposites: An overview, Macromol. Mater. Eng. 276/277 (2000), pp. 1-24.

3 J. E. Atchison, Agricultural residues and other nonwood plant fibers, Science 191 (1976), pp. 768-772.

4 P. Majumdar and S. Chanda, Chemical profile of some lignocellulosic crop residues, Indian J. Agric. Biochem. 14 (2001) (1 \& 2), pp. 29-33.

5 Staniforth, A. R. (1979) Straw for pulping, paper and board, in Cereal Straw, pp. 116-123, Clarendon Press.

6 S. K. Lim et al., Novel regenerated cellulose fibers from rice straw, J. Appl. Poly. Sci. 82 (2001), pp. 1705-1708.

7 K. G. Satyanarayana et al., Materials Science of Some Lignocellulosic Fibers, Metallography 19 (1986), pp. 389-400.

8 A. G. Kulkarni et al., Mechanical properties of banana fibres, J. Mater. Sci. 18 (1983), pp. 2290-2296.

9 G. M. Ganjyal et al., Biodegradable packaging foams of starch acetate blended with corn stalk fibers, J. Appl. Poly. Sci. 93 (2004), pp. 2627-2633.

10 Reddy, N. and Yang, Y. (2004) Structure of novel cellulosic fibers from cornhusks. Polymer Preprints (American Chemical Society, Division of Polymer Chemistry), 45 (2) 411.

11 B. Focher et al., Regenerated and graft copolymer fibers from stem-exploded wheat straw: characterization and properties, J. Appl. Poly. Sci. 67 (1998), pp. 961-974.

12 J. J. Mukherjee, Long vegetable fibres, Textile Progress 4 (1972) (4), pp. 8-9.

13 G. Henriksson et al., Identification and retting efficiencies of fungi isolated from dew-retted flax in the United States and Europe, Appl. Environ. Microb. 63 (1997), pp. 3950-3956.

14 I. Doraiswamy and P. Chellamani, Pineapple-leaf fibers, Textile Progress 24 (1993) (1), pp. 1-25.

15 L. E. Gollapalli, Predicting digestibility of ammonia fiber explosion (AFEX)-treated rice straw, Appl. Biochem. Biotechnol. 98100 (2002), pp. 23-35.

16 Tilby, E. S. Method and apparatus for processing sugarcane. US Patent No. 3567511.

17 Collier, J. R. and Collier, J. B. (1998) Process for obtaining cellulosic fiber bundles at least $2.5 \mathrm{~cm}$ long from plant stalk rind. U. S. Patent No. 5718802.

18 Moncreff, R. W. (1975) in Man-Made Fibres, pp. 162-223, Newnes-Butterworths.

19 Batra, S. K. (1985) Other long vegetable fibers, in Handbook of Fiber Science and Technology: (Vol IV: Fiber Chemistry), pp. 727808, Marcel Dekker.

20 Kirby, R. H. (1963) in Vegetable Fibres, pp. 312-355, Interscience Publishers.

21 Paster, M. et al. (2003) Industrial Bioproducts: Today and Tomorrow, Report prepared for the US Department of Energy, Washington, DC.

22 Rowell, R. M. et al. (1997) in Paper and Composites from AgroBased Resources, pp. 7-427, CRC Press.

23 Thompson, N. S. (1993) Hemicellulose as a biomass resource, in Wood and Agricultural Residues, pp. 101-115, Academic Press.

24 N. D. Saheb and J. P. Jog, Natural fiber polymer composites: a review, Adv. Polym. Tech 18 (1999), pp. 351-363.

25 Sukumaran, K. et al. Structure, physical and mechanical properties of plant fibres of Kerala. Met Mater Process. 13, 2-4, 121-136.
26 Maiti, R. (1997) in World Fiber Crops, pp. 105-108, Science Publishers.

27 S. C. Saha et al., SEM studies of the surface and fracture morphology of pineapple leaf fibers, Text. Res. J. 10 (1990), pp. 726-731.

28 S. J. Eichhorn et al., Current international research into cellulosic fibres and composites, J. Mater. Sci. 36 (2001), pp. 2107-2131.

29 N. Netravali and S. Chabba, Composites get greener, Materials Today 6 (2003) (4), pp. 22-29.

30 P. K. Ray and S. B. Bandyopadhyay, An X-ray study of coir fibre, Indian J. Phys. 39 (1965), pp. 421-427.

31 V. G. Geethamma et al., Composite of short coir fibres and natural rubber: effect of chemical modification, loading and orientation of fibre, Polymer 39 (1998), pp. 1483-1491.

32 Youngquist, J. A. et al. (1996) Agricultural fibers for use in building components. Proceedings of 1996 symposium on The Use of Recycled Wood and Paper in Building Applications, Environmental Building News. Proc. Madison, Wisconsin Forest Products Society, 123-134.

33 B. Jayanta, Plastics filled with agrowastes, Popular Plastics and Packaging 48 (2003) (11), pp. 63-74.

34 A. Ebringerova and T. Heinze, Xylan and xylan derivatives biopolymers with valuable properties, Macromol. Rapid Comm 21 (2000), pp. 542-556.

35 D. W. Sundstrom and H. E. Klei, Uses of by-product lignins from alcohol fuel processes, Biotechnol. Bioeng. Symp. 12 (1982), pp. 45-56.

36 H. R. Bungay, Confessions of a bioenergy advocate, Trends Biotechnol. 22 (2004), pp. 67-71.

37 Burger, H. et al. (1995) Use of natural fibres and environmental aspects. Int. Poly. Sci. Tech. 22, 18, T/25-T/34.

38 A. K. Mohanty et al., Sustainable bio-composites from renewable resources: opportunities and challenges in the green materials world, J. Polymer Environ 10 (2002) (1-2), pp. 19-26.

39 P. K. Banerjee et al., Investigation into homogeneity of coir fibres, Indian J. Fibre. Text. 27 (2002), pp. 111-116.

$40 \mathrm{~J}$. Gressel and A. Zilberstein, Let them eat (GM) straw, Trends Biotechnol. 21 (2003), pp. 525-530.

$41 \mathrm{M}$. N. Bora et al., Tensile properties of plant fibres readily available in north-eastern region of India, Indian J. Fibre. Text. 24 (1999), pp. 172-176.

42 S. C. Saha et al., IR and X-ray diffraction studies of raw and chemically treated pineapple leaf fiber (PALF), J. Appl. Poly. Sci. 42 (1991), pp. 2767-2772.

43 Han, J. S. (1998) Properties of nonwood fibers. In Proceedings of the Korean Society of Wood Science and Technology Annual Meeting, Seoul, Korea. The Korean Society of Wood Science and technology, 3-12.

44 R. K. Boruah et al., Microstructural study of fibres extracted from wild banana plant by X-ray line broadening analysis, Indian J. Fibre. Text. 23 (1998) (2), pp. 76-80.

45 E. Gumuskaya and M. Usta, Crystalline structure properties of bleached and unbleached wheat straw soda-oxygen pulp, Turk. J. Agric. For. 26 (2001), pp. 247-251.

46 Prabhakar, G. and Raju, D. C. (2000) Value-added chemicals from the byproducts of sugar agro industry, in Bioenergy: Vision for the New Millennium, pp. 85-91, Science Publishers.

47 Datta, R. and Tsai, S. (1997) in Fuels and Chemicals from Biomass, pp. 224-236, American Chemical Society. 